\title{
UJI AKTIVITAS ANTIBAKTERI EKSTRAK ETANOL DAUN BIDARA (Ziziphus Mauritiana Lamm) DALAM FORMULASI SEDIAAN SABUN CAIR SEBAGAI ANTISEPTIK TERHADAP BAKTERI Stapylococcus aureus ATCC 25923
}

\section{ANTIBACTERIAL ACTIVITY TEST OF BIDARA LEAF ETHANOL EXTRACT (Ziziphus Mauritiana Lamm) IN A LIQUID SOAP FORMULA ON Staphylococcus Aureus ATCC 25923 Bacteria}

\author{
Khoirunnisak $^{1}$, Wulan Agustin Ningrum ${ }^{2}$, Wirasti $^{3}$, St Rahmatullah $^{4}$ \\ ${ }^{(1,2,34)}$ Sarjana Farmasi Fakultas Ilmu Kesehatan Universitas Muhammadiyah Pekajangan \\ Pekalongan \\ Jl. Raya Ambokembang No.8, Kambang Tengah, Ambokembang, Kec. Kedungwuni, \\ Pekalongan, Jawa Tengah 51172 \\ Email :Nisakk160@gmail.com 085802476533
}

Submitted : 27 Agustus 2020 Reviewed : 25 September 2020 Accepted : 29 September 2020

\begin{abstract}
ABSTRAK
Daun bidara (Ziziphus mauritiana Lamm) mempunyai senyawa aktif seperti flavonoid, alkaloid, saponin, tanin, steroid dan terpenoid yang berfungsi untuk menghambat pertumbuhan bakteri Staphylococcus aureus. Penelitian ini bertujuan untuk memformulasikan sediaan sabun cair ekstrak daun bidara (Ziziphus mauritiana Lamm) dan menguji efektifitas antibakteri sediaan sabun cair dengan pemberian ekstrak daun bidara pada formula 1 yaitu $0,3 \%$, formula 2 yaitu $0,5 \%$ dan formula 3 yaitu $0,7 \%$. Hasil uji antibakteri pada formula 1 mempunyai daya hambat $5,0003 \mathrm{~mm}$, formula 2 mempunyai daya hambat sebesar 9,0137 $\mathrm{mm}$ dan formula 3 memiliki daya hambat sebesar 12,003 mm terhadap bakteri Staphylococcus aureus. Hasil analisis one way ANOVA pada uji antibakteri dengan nilai sig $0,00<0,05$ menunjukan adanya perbedaan dari masing-masing konsentrasi terhadap pengaruh daya hambat bakteri Staphylococcus aureus.
\end{abstract}

Katakunci : Daun bidara, Sabun cair, Staphylococcus aureus

\begin{abstract}
Leaf bidara ((Ziziphus Mauritiana Lamm) is known to have active compounds such as flavonoids, alkaloids, saponins, tanins, steroids and terpenoids which funcion tp inhibit the growth of Stapylococcus aureus bacteria. This study aims to formulate liquid soap of bidara extract leaf (Ziziphus Mauritiana Lamm) and examine the effectiveness its antibacterial soap by dripping the extract into the formulas ; $0,3 \%$ to formula $1,0,5 \%$ to formula 2 , and $0,7 \%$ to formula 3 . The result of this antibacterial test showed formula 1 has a drag of $5,0003 \mathrm{~mm}$, formula 2 has a drag of 9,0137 $\mathrm{mm}$ and formula 3 has a drag 12,003 $\mathrm{mm}$ on staphylococcus aureus bacteria. Meanwhile, the analyss result of one way ANOVA on the bacteria test with a significant value $0,00<0,05$ shows there is a different of each concentration to the effect of inhibition of Staphylococcus aureus.
\end{abstract}

Keywords : :bidara leaf, liquid soap, Staphylococcus aureus 


\author{
Penulis Korespondensi : \\ Khoirunnisak \\ Universitas Muhammadiyah Pekajangan Pekalongan \\ Jl. Raya Ambokembang No.8 - Pekalongan \\ Email :Nisakk160@gmail.com 085802476533
}

\title{
PENDAHULUAN
}

Bakteri Staphylococcus aureus merupakan suatu mikroorganisme yang biasa terdapat pada kulit. Bakteri ini merupakan bakteri gram positif yang dapat menyebabkan infeksi pada kulit dan dapat mengakibatkan keparahan infeksi seperti infeksi minor dikulit (furunkulosis dan impetigo) (Afifurrahman dkk., 2014). Pencegahan penyakit kulit akibat dari bakteri maupun jamur dapat dilakukan yaitu dengan membersikan kulit tubuh dengan menggunakan antiseptik.Antiseptik merupakan senyawa kimia yang dapat digunakan untuk menghambat ataupun mematikan mikroorganisme pada jaringan hidup, yang mempunyai efek membatasi dan mencegah infeksi agar tidak menjadi keparahan. Pemakaian antiseptik dikalangan masyarakat menengah keatas sudah menjadi suatu gaya hidup saat ini. Beberapa sediaan paten sering dijumpai dipasaran.Bentuk sediaan farmasi yang dapat digunakan untuk menjaga kesehatan kulit salah satunya adalah sabun.

Sabun merupakan suatu produk yang dihasilkan dari reaksi antara asam lemak dengan basa kuat yang berfungsi untuk mencuci ataupun membersihkan kotoran. Sabun cair saat ini penggunaannya lebih praktis dibandingkan sabun dengan bentuk yang lain karena lebih praktis dan mudah dibawa kemana-mana (Anggraini dkk.,2012). Penggunaan sabun cair sebagai antiseptik yang bersumber dari alam dapat dijadikan alternatif dalam penanganan infeksi yang diakibatkan oleh bakteri karena lebih murah dan lebih ramah lingkungan.Salah satu tanaman yang mempunyai kandungan sebagai antibakteri dengan berbagai macam mekanisme aksi adalah tanaman bidara (Ziziphus mauritiana Lamm).

Bidara (Ziziphus mauritianaLamm) merupakan tanaman yang mempunyai potensi sebagai antiseptik.Senyawa yang terkandung di dalam tanaman bidara yaitu flavonoid, alkaloid, triterpenoid, saponin, lipid dan protein.Daun bidara (Ziziphus mauritiana Lamm) dapat menghasilkan busa jika diremas, dan menghasilkan aroma yang sangat harum seperti sabun dan biasa digunakan untuk memandikan orang yang sedang sakit demam. Tanaman Bidara (Ziziphus mauritiana Lamm) khususnya pada bagian daun dalam hukum islam disunahkan untuk digunakan memandikan jenazah. Selain itu bidara juga biasa di gunakan untuk menyembuhkan orang dari gangguan sihir dengan cara mencampurkan daun bidara (Ziziphus mauritiana Lamm) mandi.

Tujuan dari penelitian ini adalah untuk mengetahui ekstrak etanol daun bidara (Ziziphus mauritiana Lamm) dapat diformulasikan dalam sediaan sabun cair antiseptik dan untuk mengetahui ekstrak etanol daun bidara (Ziziphus mauritiana Lamm) dalam formulasi sediaan sabun cair antiseptik mempunyai aktivitas sebagai antibakteri.

\section{METODE PENELITIAN}

Penelitian ini termasuk dalam desain penelitian eksperimental, dengan jenis penelitian true-experiment (Praktiknya,2010) dan merupakan penelitian yang berhubungan sebabakibat dengan adanya kelompok perlakuan dan kelompok kontrol (Nazir, 2005).

\section{Alat}

Alat yang digunakan yaitu kain hitam, pisau, blender, timbangan, ayakan, alat-alat gelas, pH universal, pipet tetes, cawan petri, ose, bunsen, inkubator, autoclave, LAF (Laminar Air Flow), jangka sorong, Piknometer,Moisturizer analysis, Rotary Evaporator, object glass, vortex, bunsen, spatula besi, pinset, dan vakum.

\section{Bahan}

Bahan yang digunakan dalam penelitian yaitu daun bidara (Ziziphus mauritiana Lamm), etanol 96\%, sodium lauril eter sulfat (SLES), gliserin, nipasol, nipagin, aquadest, $\mathrm{BaCl}_{2}$, pereaksi mayer, peraksi dragendroff, metanol, serbuk $\mathrm{Mg}$, kloroform, $\mathrm{H}_{2} \mathrm{SO}_{4}$ pekat, $\mathrm{FeCl}_{3}$ 
1\%, anhidrat asetat, HCL pekat, Mueller Hinton Agar (MHA), kertas saring, Handscoon dan masker.

\section{Pengambilan Daun Bidara}

Sampel daun bidara (Ziziphus mauritiana Lamm) diperoleh dari Desa Podo Kecamatan Kedungwuni Kabupaten Pekalongan Jawa Tengah.Daun diambil pada pagi hari pukul 08.0011.00 WIB dan bagian yang diambil adalah seluruh daun yang ada pada batang pohon kecuali daun yang masih dalam kuncup.

\section{Penyiapan Simplisia daun Bidara}

Disiapkan sampel yang akan digunakan yaitu daun bidara (Ziziphus mauritiana Lamm) sebanyak $5 \mathrm{~kg}$. Sampel dibersihkan menggunakan air bersih dan mengalir untuk menghilangkan kotoran yang menempel kemudian dipotong-potong dan dikeringkan dengan cara diangin-anginkan yang terhindar dari sinar matahari langsung. Kemudian simplisia dihaluskan dan disaring menggunakan ayakan nomor 40.

\section{Ekstraksi secara maserasi dengan Pelarut Etanol}

Serbuk daun bidara (Ziziphus mauritiana Lamm) sebanyak $1 \mathrm{Kg}$ dimasukkan ke dalam wadah maserasi, lalu ditambahkan etanol 96\% sebanyak $6000 \mathrm{~mL}$. Disimpan ditempat yang tidak terkena sinar matahari langsung dan dibiarkan selama 5 hari sambil sekali-sekali diaduk, setelah 5 hari kemudian disaring, ampasnya dimaserasi kembali dengan pelarut etanol 96\%. Hal ini dilakukan sebanyak 2 kali dengan jumlah pelarut yang sama, namun pada perlakuan ke dua dilakukan selama 3 hari. Tiap filtrat dipisahkan dari pelarutnya dengan menggunakan rotary evaporator sehingga diperoleh ektsrak kental (Hanani, 2015).

\section{Pembuatan Sabun Mandi}

Disiapkan semua bahan yang akan digunakan kemudian ditimbang dahulu sesuai dengan yang dibutuhkan. Dilarutkan SLES dalam aquades, hingga bener-bener larut dan kemudian disiapkan $\mathrm{NaCl}$ sebagai pengental dan aduk hingga homogen, disiapkan gliserin dan propilengglikol untuk ditambahkan dalam larutan. Disiapkan nipagin dan nipasol dengan cara dipanaskan diatas bara api agar dapat mencair dan menyatu dengan larutan sabun, setelah larut kemudian dicampurkan dan diaduk hingga homogen. ditambahkan ekstrak daun bidara(Ziziphus mauritiana Lamm) sesuai dengan konsentrasi dan campurkan dengan aquadest hingga $100 \mathrm{ml}$. Berikut fomulasi sabun cair yang digunakan :

\section{Tabel 1.Formula Sabun Cair}

\begin{tabular}{|c|c|c|c|c|c|}
\hline Bahan & $\begin{array}{c}\text { F0 } \\
\text { (tanpa } \\
\text { ekstrak) }\end{array}$ & $\begin{array}{c}\mathrm{F} 1 \\
(0,3 \%)\end{array}$ & $\begin{array}{c}\mathrm{F} 2 \\
(0,5 \%)\end{array}$ & $\begin{array}{c}\text { F3 } \\
(0,7 \%)\end{array}$ & Fungsi \\
\hline $\begin{array}{l}\text { Ektsrak daun bidara } \\
\text { (Ziziphus mauritiana Lamm) }\end{array}$ & - & 0,3 & 0,5 & 0,7 & Zat Aktif \\
\hline SLES & 20 & 20 & 20 & 20 & Pembusa \\
\hline $\mathrm{NaCl}$ & 3 & 3 & 3 & 3 & Pengental \\
\hline Gliserin & 2 & 2 & 2 & 2 & Emolien \\
\hline Propilengglikol & 3 & 3 & 3 & 3 & Humektan \\
\hline Nipasol & 0,002 & 0,002 & 0,002 & 0,002 & Pengawet \\
\hline Nipagin & 0,001 & 0,001 & 0,001 & 0,001 & Pengawet \\
\hline Aquadest & $\begin{array}{c}\text { Ad } \\
100 \mathrm{ml}\end{array}$ & $\begin{array}{c}\mathrm{Ad} \\
100 \mathrm{ml}\end{array}$ & $\begin{array}{c}\text { Ad } \\
100 \mathrm{ml}\end{array}$ & $\begin{array}{c}\text { Ad } \\
100 \mathrm{ml}\end{array}$ & Pelarut \\
\hline
\end{tabular}




\section{Pemeriksaan stabilitas fisik sediaan}

Uji stabilitas fisik sediaan dilakukan dengan cara Cycling test. Parameter yang diamati pada uji stabilitas fisik sediaan yaitu uji organoleptis dan homohenitas, uji $\mathrm{pH}$ dan uji viskositas. Pada saaat pengujian stabilitas sediaan sabun cair antiseptik disimpan pada suhu $4^{\circ} \mathrm{C} \pm 2{ }^{\circ} \mathrm{C}$ selama 24 jam lalu keluarkan dan tempatkan pada suhu $40^{\circ} \mathrm{C}$ selama 24 jam. Perlakuan ini adalah satu siklus. Percobaan diulang sebanyak 6 siklus. Kondisi sediaan dibandingkan sebelum dan sesudah uji tersebut (Rachma, 2010).

\section{Pembuatan Media MHA}

Disiapkan MHA sebanyak 5,7 gram dan aquadest $150 \mathrm{ml}$. MHA (Mualler Hinton Agar) dipanaskan diatas hot plate yang didalamnya sudah terdapat magnetik stirrer hingga mendidih. Kemudian disterilkan menggunakan sterilisasi panas uap di autoklaf pada suhu $121^{\circ} \mathrm{C}$ selama 20 menit. Kemudian di tuang ke dalam cawan petri yang sudah di sterilisasi, kemudian diamkan hingga dingin dan disimpan di dalam kulkas selama 24 jam.

\section{Pengujian Daya hambat Sabun Cair Ekstrak daun Bidara}

Penentuan aktivitas antibakteri mengacu pada skripsi yang dibuat oleh Eko Prayoga 2013 dengan judul " Perbandingan Efek Ekstrak Daun Sirih Hijau (Piperbetle L.) Dengan Metode Difusi Disk dan Sumuran Terhadap Pertumbuhan Bakteri Stapylococcus aureus".Pada penelitian ini penentuan aktivitas antibakteri dilakukan dengan metode difusi sumuran dan dengan menggunakan media MHA. Uji aktivitas antibakteri sabun cair antiseptik ekstrak daun bidara (Ziziphus mauritiana Lamm) dilakukan dengan cara mengencerkan bakteri dengan mencampur 1 ose suspensi bakteri Staphylococcus aureus ke dalam tabung reaksi yang telah berisi larutan $\mathrm{NaCl}$ dan telah di standarisasi sesuai konsentrasi 0,5 Mc Farland kemudian mengulaskan suspensi bakteri menggunakan ose yang sudah disterilkan pada permukaan media MHA. Dibuat lubang dimedia sebanyak 5 lubang. 3 lubang untuk 3 formulasi 1 lubang untuk kontrol positif dan 1 lubang untuk kontrol negatif.Kemudian dimasukan formulasi sabun cair yang sudah dibuat beserta kontrol negatif dan positif di media MHA yang sudah dilubangi dengan menggunakan mikropipet.Kemudian diinkubasi ke dalam inkubator pada suhu $37^{\circ} \mathrm{C}$ selama 24 jam. Setelah 24 jam diamati dan diukur diameter zona terang (clear zone) yang terbentuk di sekitar lubang dengan menggunakan jangka sorong.

\section{Analisis data}

Analisis data yang digunakan yaitu analisis secara one-way ANOVA versi 16 (Tapehe, 2014). Analisis ANOVA (Analysis of variance) digunakan untuk pengujian sebuah rancangan eksperimen dengan rancangan lebih dari dua (Riwidikdo, 2008) dan pemilihan analisis secara one-way ANOVA didasarkan penelitian pada satu kriteria (Tapahe, 2014).. Jika pada uji ANOVA menghasilkan nilai $\mathrm{p}<0,05$ maka dilanjutkan dengan analisis Post Hoc untuk mengetahui perbedaan yang bermakna (Dahlan, 2009).

\section{HASIL DAN PEMBAHASAN}

Pengujian ini bertujuan untuk mengetahui apakah ekstrak daun bidara dapat dijadikan formulasi sediaan sabun cair dengan baik.Maka pada penelitian ini dilakukan uji cycling test.Cycling test dilakukan untuk menguji stabilitas formulasi sediaan apakah mengalami kristalisasi atau berawan dan untuk menguji kestabilan sediaan minyak dalam air (Wilinson, 1982). Uji Cycling test dilakukan dengan cara sediaan sabun cair disimpan pada suhu $2^{\circ} \mathrm{C}$ dan pada suhu $40^{\circ} \mathrm{C}$. Hasil pengamatan dari cycling test selama 6 siklus pada sediaan sabun cair antiseptik ekstrak daun bidara (Ziziphus mauritina Lamm) meliputi pengamatan organoleptis, pengukuran viskositas dan pengukuran $\mathrm{pH}$. 
Tabel. 2 hasil pengamatan uji organoleptis sediaan sabun cair antiseptik ektrak daun bidara

\begin{tabular}{|c|c|c|c|}
\hline \multirow[t]{2}{*}{ Formula } & & \multicolumn{2}{|c|}{ Parameter } \\
\hline & & Sebelum & Sesudah \\
\hline 1. $\quad(0,3 \%)$ & $\begin{array}{c}\text { Warna } \\
\text { Bau } \\
\text { Konsistensi } \\
\text { Kejernihan }\end{array}$ & $\begin{array}{c}\text { Kekuningan } \\
\text { Khas bidara } \\
\text { Cairan kental } \\
\text { Jernih }\end{array}$ & $\begin{array}{c}\text { Kekuningan } \\
\text { Khas bidara } \\
\text { Cairan agak } \\
\text { kental } \\
\text { Jernih }\end{array}$ \\
\hline 2. $\quad(0,5 \%)$ & $\begin{array}{c}\text { Warna } \\
\text { Bau } \\
\text { Konsistensi } \\
\text { Kejernihan }\end{array}$ & $\begin{array}{c}\text { Hijau kekuningan } \\
\text { Khas bidara } \\
\text { Cairan kental } \\
\text { Jernih }\end{array}$ & $\begin{array}{c}\text { Hijau kekuningan } \\
\text { Khas bidara } \\
\text { Cairan agak } \\
\text { kental } \\
\text { Jernih }\end{array}$ \\
\hline 3. $\quad(0,7 \%)$ & $\begin{array}{c}\text { Warna } \\
\text { Bau } \\
\text { Konsistensi } \\
\text { Kejernihan }\end{array}$ & $\begin{array}{c}\text { Hijau tua } \\
\text { kekuningan } \\
\text { Khas bidara } \\
\text { Cairan kental } \\
\text { Jernih }\end{array}$ & $\begin{array}{c}\text { Hijau tua kekuningan } \\
\text { Khas bidara } \\
\text { Cairan agak } \\
\text { kental } \\
\text { Jernih }\end{array}$ \\
\hline
\end{tabular}

(Data diolah 2020)

Hasil dari uji organoleptis dan homogenitas sediaan sabun cair antiseptik ekstrak daun bidara dapat dikatakan stabil baik sebelum ataupun sedudah perlakuan, karena tidak ada perubahan warna , bau, rasa maupun kejernihan. Kestabilan yang terjadi dapat dipengaruhi oleh kemasan yang tertutup dengan baik dan benar (Soehatmo dkk, 2014).

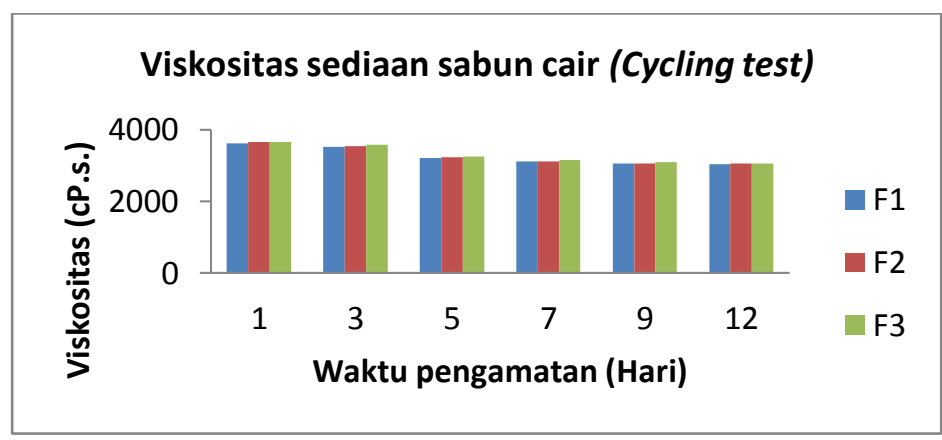

Gambar 1. Nilai Viskositas cycling test sediaan sabun cair ekstrak daun bidara (Zizhipus mauritiana Lamm)

(Sumber : Pribadi, 2020)

Hasil dari uji viskositas yang didapatkan maka dapat diketahui bahwa sediaan sabun cair antiseptik ekstrak etanol daun bidara dapat dikatakan baik karena nilai viskositasnya paling rendah adalah 3035 cP.s. dan yang paling tinggi adalah 3668 cP.s. dari semua formula yang telah diuji. Sediaan sabun cair antiseptik dikatakan bagus apabila nilai viskositasnya dalam rentang antara 500-20.000 cP.s. (Soehatmo dkk, 2014). Kemudian hasil yang di dapat dianalisis menggunakan One-way ANOVA dan didapatkan nilai $0,971>0,05$ yang menunjukan bahwa tidak ada perbedaan yang signifikan nilai viskositas pada formula 1 . Formula 2 dan formula 3. 


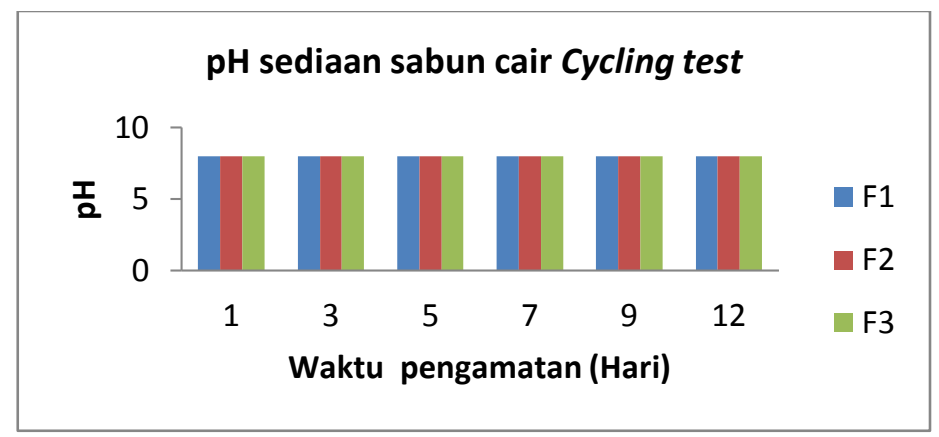

Gambar 2 Nilai pH cycling test sediaan sabun cair ekstrak daun bidara (Zizhipus mauritiana Lamm)

(Sumber : Pribadi, 2020)

Kemudian hasil pH pada formula 1, 2 dan 3 memiliki nilai yang sama yaitu 8 . Hasil yang didapatkan sesuai dengan persyaratan sediaan sabun cair yaitu masih dalam rentan $\mathrm{pH}$ 6-8 (Soehatmo dkk, 2014).

Formula sediaan sabun cair ekstrak daun bidara (Ziziphus mauritina Lamm) dapat menghambat pertumbuhan bakteri Staphylococcus aureus. Pengujian ini dilakukan menggunakan metode sumuran karena merupakan metode yang lebih efektif dalam pengujian bakteri. Pengujian ini menggunakan kontrol negatif berupa sediaan sabun cair tanpa adanya ekstrak daun bidara (Ziziphus mauritina Lamm) dengan komposisi yang sama terhadap formulasi sediaan sabun cair yang dibuat, kontrool positif adalah sediaan sabun cair merek X. Menurut ambarwati (2007) klasifikasi respon hambatan pertumbuhan bakteri dapat dilihat berdasarkan diameter zona bening yang terdiri atas 4 kelompok yaitu respon lemah (diameter $\leq 5 \mathrm{~mm}$ ), sedang (diameter 5-10 mm), kuat (diameter 10-20 mm) dan sangat kuat (diameter $\geq 20 \mathrm{~mm}$ ). Berdasarkan klasifikasi tersebut hasil pengamatan diameter hambatan sediaan sabun cair ekstrak daun bidara (Ziziphus mauritina Lamm) terhadap pertumbuhan bakteri Staphylococcus aureus setelah masa inkubasi 1x24 jam. Berikut adalah hasil dari uji daya hambat sabun cair ekstrak daun bidara

Tabel 3. Hasil uji daya hambat sabun cair ekstrak daun bidara

\begin{tabular}{ccccc}
\hline Formulasi & \multicolumn{3}{c}{ Replikasi Diamter Hambat } & Rata-rata \\
\cline { 2 - 4 }$(\%)$ & $\mathrm{i}$ & $\mathrm{Ii}$ & $\mathrm{iii}$ & \\
\hline F1 $(0,3)$ & 4,967 & 5,047 & 4,987 & $5,0003 \mathrm{~mm}$ \\
F2 $(0,5)$ & 8,967 & 9,047 & 9,027 & $9,0137 \mathrm{~mm}$ \\
F3 $(0,7)$ & 11,967 & 12,047 & 11,987 & $12,003 \mathrm{~mm}$ \\
K+ (merek X) & 19,12 & 19,14 & 19,10 & $19,12 \mathrm{~mm}$ \\
K- (Tanpa ekstrak) & 0 & 0 & 0 & 0 \\
\hline
\end{tabular}
Keterangan :
F1 : Formulasi 1
F2 : Formulasi 2
F3 : Formulasi 3
$\mathrm{K}+:$ Kontrol +
$\mathrm{K}$ - : Kontrol - 
(Data diolah 2020)

Hasil dari pengamatan pada inkubasi selama 24 jam diperoleh rata-rata zona hambat terbesar pada formula 3 yaitu 12,003 mm dengan kategori daya hambat kuat, sedangkan pada formula 2 diperoleh zona hambat sebesar $9,0137 \mathrm{~mm}$ yang termasuk dalam kategori daya hambat sedang dan pada formulasi 1 diperoleh zona hambat sebesar 5,0003 $\mathrm{mm}$ yang termasuk dalam kategori sedang. Hal ini dikarenakan konsentrasi ekstrak yang ditambahkan pada formula satu lebih kecil dari pada formula 2 dan 3. Hasil dari kontrol positif yaitu 19,12 $\mathrm{mm}$ yang termasuk dalam kategori kuat. Gambar hasil uji daya hambat dapat dilihat pada gambar 3 .

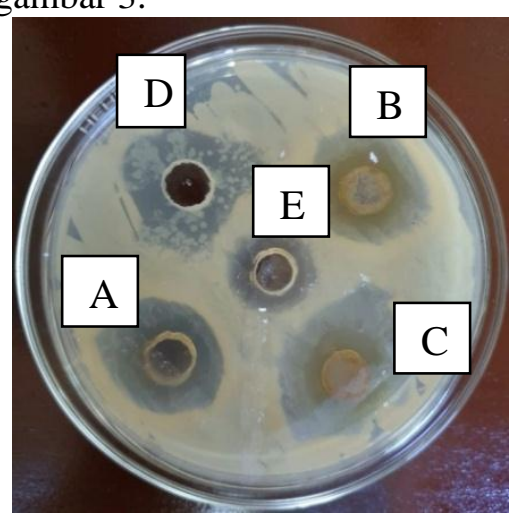

Replikasi 1

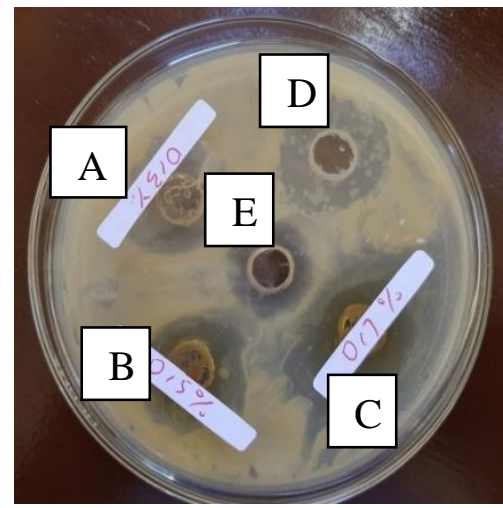

Replikasi 2

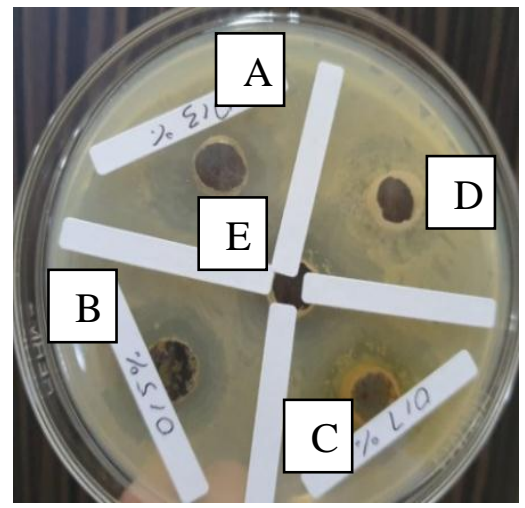

Replikasi 3

Gambar 3. Hasil uji daya hambat sabun cair ekstrak daun bidara

\author{
Keterangan \\ A : Formula $1(0,3 \%)$ \\ B : Formula $2(0,5 \%)$ \\ C : Formula $3(0,7 \%)$ \\ D : Kontrol positif (merek x) \\ $\mathrm{E}$ : Kontrol negative (tanpa ekstrak)
}

Tujuan digunakannya kontrol positif adalah untuk membandingkan hasil sediaan sabun cair ekstrak daun bidara (Ziziphus mauritina Lamm) yang dibuat dengan sabun cair yang sudah beredar dipasaran apakah dapat menghambat bakteri secara baik ataupun tidak. Dari hasil yang didapatkan menunjukan bahwa semakin besar konsentrasi ekstrak yang digunakan maka semakin besar pula zona hambat yang terbentuk disekeliling sumuran. Besar ataupun kecilnya zona hambat disebabkan oleh adanya variasi ekstrak yang terdapat pada masing-masing sediaan, formula 1 digunakan ekstrak sebesar 0,3 gram dalam $100 \mathrm{ml}$, pemilihan konsentrasi ini berdasarkan pada penelitian dan sesuai dengan hasil orientasi ekstrak daun bidara (Ziziphus mauritina Lamm) yang telah dilakukan. Kemudian pada formulasi 2 digunakan ekstrak sebanyak 0,3 gram dalam $100 \mathrm{ml}$ sementara pada formulasi 3 digunakan esktrak sebanyak 0,7 gram dalam $100 \mathrm{ml}$, digunakan konsentrasi yang berbeda dengan tujuan untuk mengetahui nilai optimum dari aktivitas penghambatan antibakteri Staphylococcus aureus. Berdasarkan pernyataan Plezer dan Chan (1989) bahwa semakin tinggi konsentrasi suatu bahan antibakteri maka aktivitas antibakterinya semakin kuat. Hasil ini juga didukung oleh pernyataan Perwata dan Dewi (2008) bahwa efektifitas suatu zat antibakteri dipengaruhi oleh konsentrasi zat tersebut. Zona bening yang terlihat disekitar sumuran menunjukan mengandung senyawa-senyawa yang bersifat sebagai antibakteri diantaranya adalah alkaloid, flavonoid, saponin, tanin, steorid dan terpenoid hal ini diperkuat dengan hasil uji skrinning fitokimia bahwa ekstrak daun bidara (Ziziphus mauritina Lamm) positif mengandung Alkaloid, Flavonoid, Saponin, Tanin, steroid dan Terpenoid. Menurut Suerni dkk (2013) flavonoid merupakan senyawa yang cenderung bersifat polar, kepolaran senyawa inilah yang mengakibatkan senyawa lebih mudah menembus dinding sel bakteri dengan cara mendenaturasi protein bakteri yang dapat menyebabkan berhentinya aktivitas 
metebolisme protein bakteri. Sedangkan tanin merupakan senyawa polifenol yang memiliki berat molekul 500-3000 dalton yang diduga berperan sebagai antibakteri, karena dapat membentuk kompleks dengan protein dan interaksi hidrofobik. Mekanisme tanin sebagai antibakteri adalah dengan merusak membran sel bakteri, senyawa astrigen tanin dapat menginduksi pembentukansenywa ikatan kompleks terhadap enzim atau substrak mikro (Saifudin dkk, 2011). Mengetahui adanya perbedaan hambat sediaan sabun cair ekstrak daun bidara (Ziziphus mauritina Lamm) terhadap bakteri Staphylococcus aureus dilakukan analisis data menggunakan analisis data one-way ANOVA yang diperoleh nilai sig $0,00<$ 0,05 . Hal ini menunjukan bahwa hasil zona hambat pertumbuhan bakteri terdapat perbedaan yang signifikan antara formula 1, formula 2 dan formula 3 serta daya hambat yang paling baik terdapat pada formula ke-3 yaitu sebesar 12,003 $\mathrm{mm}$.

\section{KESIMPULAN}

Berdasarkan penelitian yang telah dilakukan dapat disimpulkan bahwa Formula sediaan sabun cair ekstrak daun bidara (Ziziphus mauritina Lamm) mempunyai daya hambat pertumbuhan bakteri Staphylococcus aureus sebesar 5,0003 $\mathrm{mm} ; 9,0137 \mathrm{~mm}$; $12,003 \mathrm{~mm}$ yang berturut, turut untuk F1, F2 dan F3. Daya hambat pertumbuhan bakteri Staphylococcus aureus terbesar yaitu pada F3 sebesar 12,003 mm.

\section{UCAPAN TERIMA KASIH}

Ucapan terima kasih peneliti kepada orang tua seluruh dosen dan karyawan serta rekan sejawat farmasi Universitas Muhammadiyah Pekajangan Pekalongan atas segala partisipasi doa dan semangat dalam pelaksanaan penelitian.

\section{DAFTAR PUSTAKA}

Afifurrahman, Samadin, K. H., \& Aziz, \&. S. (2014).Pola Kepekaan bakteri Straphylococcus aureus terhadap antibiotik vancomycin di RSUP Dr. Muhammad Hoesin Palembang. MKS.Vol.46 (4)p266-270.

Ambarwati. (2007). Efektivitas Zat Antibakteri Biji Mimba (Azadicarata Indica) untuk Menghambat Pertumbuhan Salmonella thyposa dan Staphylococcus aureus. Jurnal Biodervisitas. Surakarta . Prodi Kesehatan Masyarakat, Fakultas Ilmu Kesehatan, Universitas Muhammadiyah Surakarta.

Agustina, L., Yulianti. M., Shoviantari. F., \& Sabban. \& I. (2017). Formulasi dan Evaluasi Sabun Mandi Ekstrak Tomat (Solanum Lycopersicum L.) Sebagai Antioksidan. Journal Wiyata.Vol 4 (2) p99-105.

Anggraini, L., Yulianti, M., Shoviantri, F., \& Sabban, \&, I. (2017).Formulasi dan Evaluasi Sabun Mandi Cair dengan Ekstrak Batang Nanas (Ananas comosus L.) untuk Mengatasi Jamu Candida albicans.Jurnal Pengelitian Farmasi Indonesia. Vol. 1 (1) p30-33.

Hanani, E. (2015). Analisis Fitokimia. Jakarta: EGC.

Praktiknya, A. W. (2010). Dasar-dasar metodologi penelitian kedokteran \&kesehatan. Jakarta : Rajawali press.

Prasetyo \& Inoriah, E. (2013). Pengelolaan Budidaya Tanaman Obat-Obatan (bahan simplisia). Bengkulu: Badan Penelitian Fakultas Pertanian UNIB.

Prayoga, Eko. (2013). Perbandingan Efek Ekstak Daun Sirih Hijau (Piper batle L) Dengan Metode Difusi Disk \& Sumuran Terhadap Pertumbuhan Bakteri Stapylococcus aureus. Skripsi. Fakultas Kedokteran dan Ilmu Kesehatan, Universitas Islam Negeri Syarif Hidayatullah Jakarta.

Saifudin, A., Rahayu, V., \& Teruna.H. (2011).Standardisasi bahan obat alam. Yogyakarta: Ghaha Ilmu.

Soehatmo, H., Limantara, T. H., \& Leenawaty. (2014). Pemanfaatan Klorofilin dalam Pembuata Sabun Cuci Tangan Cair.Symbol. Vol. 1 (1)p95-104. 
Suerni, E., Muhammad, A. dan Musjaya, G,. (2013). Uji Daya Hambat Ekstrak Buah Nanas (Ananas comocus L. Merr), Salak (Salacca edulis Reniw) dan Mangga Kweni (Mangifera adorata Griff)terhadap Daya Hambat Stapylococcus aureus. Biocelebes. Vol.7 (1) p36-47.

Tapehe,Y. (2014). Stastika dan rancangan percobaan.Jakarta : EGC. 
